\title{
Determination of Nonylphenol, Octylphenol and Bisphenol-A in Water and Sediments of Two Major Rivers in Lagos, Nigeria
}

\section{Adebola A. Oketola, Taiwo K. Fagbemigun}

Department of Chemistry, University of Ibadan, Ibadan, Nigeria.

Email: bolaoketola@yahoo.com, khayorde86@yahoo.com

Received April 30 ${ }^{\text {th }}, 2013$; revised June $5^{\text {th }}, 2013$; accepted July $8^{\text {th }}, 2013$

Copyright (C) 2013 Adebola A. Oketola, Taiwo K. Fagbemigun. This is an open access article distributed under the Creative Commons Attribution License, which permits unrestricted use, distribution, and reproduction in any medium, provided the original work is properly cited.

\begin{abstract}
The continuous uncontrolled discharge of pollutants into aquatic systems in developing countries like Nigeria has prompted a more sensitive assessment of the level of pollutants inhabiting the environment. Sediments and waters of River Ogun and River Ibeche in southwestern part of Nigeria were collected and analysed for 4-t-Octyphenol (4-t-OP), 4-nonylphenol (4-NP) and Bisphenol-A (BPA), that have been shown to possess endocrine-disrupting properties. Prior to analysis by GC-MS technique, targeted compounds were extracted from samples by ultrasonication and liquid-liquid extraction, respectively. Physicochemical properties of the samples such as temperature, $\mathrm{pH}$, total organic carbon and particle size distribution were also determined. 4-NP and 4-t-Op were detected in all the water samples with concentration ranging between $43.9 \mathrm{ng} / \mathrm{L}-79.4 \mathrm{ng} / \mathrm{L}$ and $57.1 \mathrm{ng} / \mathrm{L}-68.6 \mathrm{ng} / \mathrm{L}$, respectively. No trace of BPA was found in all the water samples collected. However, BPA in sediment samples from both rivers ranged from non detectable to $\leq 0.4$ $\mathrm{ng} / \mathrm{g}$, while 4-t-OP and 4-NP were between $2.2 \mathrm{ng} / \mathrm{g}-24.5 \mathrm{ng} / \mathrm{g}$ and $1.1 \mathrm{ng} / \mathrm{g}-79.4 \mathrm{ng} / \mathrm{g}$, respectively. The presence of these compounds in surface water and sediments may be attributed to the release of pollutants into the studied rivers from both domestic and industrial activities. Further studies are however needed to investigate the potential ecological and health effects of these compounds on aquatic organisms that inhabit the rivers.
\end{abstract}

Keywords: Endocrine Disrupting Compounds; Surface Water; Sediment; Pollution

\section{Introduction}

Poor enforcement of water pollution control laws and regulations has led to an astronomical increase in pollution of rivers and streams in developing countries like Nigeria. Consequently, massive amount of wastewater and effluents are discharged indiscriminately into aquatic systems across the country. These discharges are known to contain different types of contaminants that have the tendency to threaten humans and wildlife. Of particular concerns, however, are the phenolic endocrine disrupting compounds (EDCs), which include bisphenol-A (BPA), alkylphenol ethoxylates (APEs) and their degradation products such as nonylphenol and octylphenol etc, which have been declared toxic [1].

Endocrine disrupting compounds also referred to as hormonally active agents or endocrine disrupting chemicals (EDC) [2] are exogenous agent that interferes with the synthesis, secretion, transport, metabolism, binding action or elimination of natural blood-borne hormones that are present in the body and are responsible for homeostasis, reproduction and developmental processes. These compounds have attracted a great deal of scientific and public attention worldwide due to their widespread occurrence as environmental contaminants and potential adverse effects on the normal reproduction and development of environmentally exposed organisms [3-5].

Alkyphenols are used mainly to make phenolic resins used in rubber processing to make tyres and in printing inks, electrical insulation, varnishes and in the production of ethoxylated resin for offshore oil receiver [6]. They also find application as building block chemicals that are used in making fragrances, surfactants, thermoplastic elastomers, antioxidants, adhesives, coatings, carbonless copy-paper and high performance rubber paper [7]. The distribution of nonylphenol in aquatic environment in several rivers in Europe and USA has been reported 
where it has been found to be mainly concentrated in sediment [3,5,8-10]. Various studies have also confirmed that nonylphenol present risks to aquatic organisms, especially zooplanktons and benthic macro-invertebrates in areas of high chronic exposure to high concentrations $[11,12]$. They have so far been found to exert toxicity and estrogenic effects on aquatic organisms with attendant effects on human health [13]. Consequently, both nonylphenol and octylphenol have been categorized as definitely endocrine disruptors particularly in aquatic organisms $[14,15]$.

Bisphenol-A has received great attention due to its potential association with adverse health effects such as prostate cancer, obesity, neurobehavioral and reproductive problems [16]. BPA migrates from polycarbonate flasks and increased the rate of proliferation of human breast cancer cells [17]. Leaching of BPA was attributed to the migration of residual BPA not bonded to the polymer in polycarbonate and in epoxy resin. Release of BPA can also occur from polycarbonate hydrolysis in extreme conditions [18]. Migration of BPA from several kinds of plastic to human and various environmental media is therefore a significant problem [19]. Many studies have therefore confirmed the presence of BPA in soil and aquatic environments as well as the widespread and continuous human exposure to BPA through food, drinking water, dental sealants, cell phones and inhalation of indoor dusts [20-25].

The aim of this study was to investigate the level of endocrine disrupting compounds such as octylphenol (4-t-OP), nonylphenol (4-NP), and bisphenol-A (BPA) in river water and sediment samples. Knowledge of the occurrence and level of these compounds in environmental matrices will serve as an indication of the extent of aquatic contamination and provides veritable information on the potential accumulation characteristics in the aquatic system in Nigeria.

\section{Experimental}

\subsection{Chemicals}

High purity standards (purity $>97 \%$ ) of three targeted phenolic compounds (4-t-OP, 4-NP, BPA) were purchased from Merck, (Germany) and internal standards; 4-nnonylphenol and BPA-d16 from Sigma-Aldrich (Buchs, Switzerland). Individual stock solutions of the studied compounds were prepared in methanol and stored at $20^{\circ} \mathrm{C}$. Organic solvents (methanol, dichloromethane and hexane) used for sample processing and analysis were HPLC grade and purchased from Multisolvent (Scharlau, Switzerland). All glassware was clean properly and solvent-rinsed before use.

\subsection{Study Area}

Sediment and water samples were collected from two rivers in Lagos, Nigeria. River Ogun is one of the main rivers in the southwestern part of Nigeria with a total area of $22.4 \mathrm{~km}^{2}$ and a fairly large flow of about 393 $\mathrm{m}^{3} \cdot \mathrm{sec}^{-1}$ during the wet season. The river is one of the two principal rivers in the Ogun-Osun River Basin of Nigeria with the characteristics of a tropical climate. It takes its source in Oyo State (Latitude: $6.5922222^{\circ}$, Longitude: $3.4616667^{\circ}$ ) near Shaki and flows through Ogun State before discharging into Lagos Lagoon. Its reservoir capacity is about 690 million $\mathrm{m}^{3}$ and has a cattle market located along its course at Isheri. Different wastes (mostly organics) from the market are usually discharged into it. The water is used for agriculture, transportation, human consumption, various industrial activities and domestic purposes. River Ibeche is one of the oldest rivers in Nigeria. It receives effluent discharge from the textile industry located at Ibeshe town in Ikorodu. Over the years the water has been utilized for domestic purposes by the dwellers of the community. However, in recent times the water has been totally abandoned due to its extreme pollution caused by the continuous discharge of effluents from the textile company located along the riverside.

\subsection{Sample Collection}

The rivers were divided into 3 sections; upstream, midstream and downstream. Two composite samples $(n=10)$ of sediment were collected from each section to make a total of 6 composite samples per river and 12 representative samples from both rivers. For water sample, one (1) composite sample $(\mathrm{n}=10)$ of water was collected from each section to make a total of 3 composite samples per river and 6 representative samples from both rivers. $1.0 \mathrm{~g}$ of sodium azide was added to each of the sediment samples to inhibit microbial growth. This was done to fix the organic matter and also to retard any possible decay. Concentrated hydrochloric acid $(\mathrm{pH} \leq 2)$ was added to the water samples to avoid any degradation of the target compounds. All samples were collected into a glass bottle and stored by refrigeration prior to analysis, which was done almost immediately after sample collection.

\subsection{Sample Preparation}

Sediment samples were first ground and homogenized using a mortar and pestle in an anhydrous sodium sulphate. About $5 \mathrm{~g}$ of dried and homogenized sediment sample was weighed into a centrifuge tube, spiked with solution of internal standards $(100 \mu \mathrm{L}$ each of $1 \mathrm{mg} / \mathrm{L}$ 4-n-NP and BPA-d16) and $25 \mathrm{~mL}$ of a mixture of dichloromethane and hexane (2:1) was added. The tube 
was sonicated for $15 \mathrm{~min}$ and then centrifuged at 1500 rpm for $5 \mathrm{~min}$. The extraction was repeated with $10 \mathrm{~mL}$ of the solvent mixture. The extracts were combined, concentrated to about $2.0 \mathrm{~mL}$ and dried over anhydrous sodium sulfate. Liquid-liquid extraction was used to extract water samples. 1 litre of water sample was first filtered through glass fibre filters (whatman GF/F, $1 \mu \mathrm{m}$ effective pore size) to remove suspended particles. 100 $\mu \mathrm{L}$ each of $1 \mathrm{mg} / \mathrm{L}$ of $4-\mathrm{n}-\mathrm{NP}$ and BPA-d16 were added to the filtrate as internal standards. Extraction was carried out first with $50 \mathrm{~mL}$ dichloromethane and then with 25 $\mathrm{mL}$ hexane. All extracts were combined and dried over anhydrous sodium sulphate. For all extraction procedures, methanol was added to enhance the isolation of analytes, particularly bisphenol-A. Clean-up of the extracts was achieved with a glass syringe $(20 \mathrm{~mL})$ loaded with silica gel, glass wool and anhydrous sodium sulphate and then eluted with $5 \mathrm{~mL}$ of a mixture of dichloromethane and hexane (2:1). The syringe was first conditioned by soaking in hexane before and after packing. The purified extracts were then re-constituted in $2 \mathrm{~mL}$ hexane. Total organic carbon (\% TOC) of each sediment sample was estimated using the Walkley-black titration method [26] while sediment particle size distribution was determined using the hydrometer method.

\subsection{Derivatisation}

Due to the low volatility of targeted compounds, derivatisation was essential to enhance the suitability of the analytes for detection by gas chromatography. The purified extracts were derivatised by reacting with acetic anhydride [27]. $100 \mu \mathrm{L}$ of purified extract was transferred into a glass tube, followed by the addition of $2 \mathrm{~mL}$ of $1 \mathrm{M} \mathrm{NaHCO}_{3}$ and $1 \mathrm{~mL}$ of $1 \mathrm{M} \mathrm{NaOH}$ solutions. The tube was mixed for few seconds to dissolve the extract. 2 $\mathrm{mL}$-hexane and $10 \mathrm{~mL}$ acetic anhydride were then added. The tube, tightly capped and manually shaken violently for $1 \mathrm{~min}$, was then left at room temperature for 30 minutes. The supernatant of $n$-hexane was transferred carefully into a glass centrifugal tube using a glass pipette. The n-hexane mixture was then allowed to dry on standing. The dried extract was re-dissolved in $100 \mu \mathrm{L}$ of n-hexane and transferred into a $2 \mathrm{~mL}$ amber glass vial.

\subsection{Instrumental Analysis}

The derivatised extracts were analysed for the targeted compounds; BPA, OP and NP using a gas chromatograph equipped with a mass spectrometer. Separation of all targeted compounds was achieved by injecting about $1 \mu \mathrm{L}$ of each extract into the GC system (in a splitless mode) through a capillary column $(3.0 \mathrm{~m}$ length, $0.2 \mathrm{~mm}$ internal diameter, $0.2 \mu \mathrm{m}$ film thickness). Helium gas was used as the carrier gas. Tables $\mathbf{1}$ and $\mathbf{2}$ summarize the GC/MS condition adopted in the procedure as well as the characteristic retention time of the targeted compounds. Quantification was carried out by the use of a computer integrator. A 5-point relative response factor (RRF) calibration curve was established for analytes of interest prior to the analysis of samples. The mean relative response factor was determined for each calibration level. Sample analyte concentrations were calculated based on the concentration and response of the internal standard.

\subsection{Quality Control/Assurance}

Simultaneous extraction of the phenolic EDCs was carried out and all data generated from the analysis were subjected to strict quality control procedures. With each set of samples analysed, a solvent blank and a standard were run in sequence to check for background contamination, peak identification and quantification. In addition, internal standards, $100 \mu 1$ of $1 \mathrm{mg} / \mathrm{L}$ of $4-n-N P$ and BPA-

Table 1. Operational conditions of GC/MS.

\begin{tabular}{cc}
\hline GC/MS: & Agilent Technologies $7890 \mathrm{~A}, 5975 \mathrm{MSD}$ \\
\hline Column: & $\begin{array}{c}\text { HP-5 } 19091 \mathrm{~J}-413 \text { Capillary column } \\
(30 \mathrm{~m}, 0.32 \mathrm{~mm}, 0.25 \mu \mathrm{m})\end{array}$ \\
Injection method: & Splitless mode \\
Injection Volume: & $1.0 \mu \mathrm{L}$ \\
Carrier gas: & Helium gas $(1.8 \mathrm{~mL} / \mathrm{min})$ \\
Injection temperature: & $300^{\circ} \mathrm{C}$ \\
$\begin{array}{c}\text { Oven Temperature } \\
\text { Programme: }\end{array}$ & GC Oven Temperature was kept \\
at $50^{\circ} \mathrm{C}$ for 2 min \\
First ramp at $10^{\circ} \mathrm{C} / \mathrm{min}$ to $220^{\circ} \mathrm{C}$ \\
MS Mode & Second ramp $12^{\circ} \mathrm{C} / \mathrm{min}$ to $260^{\circ} \mathrm{C}$ \\
Ion Source Temperature & Final temperature $3^{\circ} \mathrm{C} /$ min to $300^{\circ} \mathrm{C}$ \\
Interface temperature & Selected Ion monitoring (SIM) mode \\
\hline
\end{tabular}

Table 2. Details of the phenolic endocrine disrupting chemicals and their characteristics ions and retention times.

\begin{tabular}{cccc}
\hline Compounds & $\begin{array}{c}\text { Retention time } \\
(\mathrm{min})\end{array}$ & $\begin{array}{c}\text { Molecular } \\
\text { weight }\end{array}$ & $\begin{array}{c}\text { Quantification ion } \\
\text { (base ions, m/z) }\end{array}$ \\
\hline 4-t-OP & 13.38 & 206.33 & 207 \\
4-NP & 13.96 & 220.36 & 179 \\
4-n-NP & 14.56 & 220 & 414.2 \\
BPA-d16 & 22.89 & 244 & 368 \\
BPA & 24.62 & 228.29 & 228 \\
\hline
\end{tabular}


d16, were added to all the samples to monitor matrix effects and for recovery studies. Linearity of the instrument response was ascertained by analyzing standard solutions at different concentration levels in the range 10 $\mu \mathrm{g} / \mathrm{L}-100 \mu \mathrm{g} / \mathrm{L}$. Limit of detection (LOD) and limit of quantitation (LOQ) were calculated based on the standard deviation of the response and slope of the calibration plots. Relative recoveries, LOD and LOQ of the targeted compounds are highlighted in Tables 3 and 4.

$$
\begin{aligned}
& \mathrm{LOD}=3.3 \times(\mathrm{s} / \mathrm{S}) \\
& \mathrm{LOQ}=10 \times(\mathrm{s} / \mathrm{S}) \\
& \mathrm{s}=\text { standard deviation of } \mathrm{y} \text {-intercepts; } \\
& \mathrm{S}=\text { slope of the calibration curves. }
\end{aligned}
$$

\section{Results and Discussion}

\subsection{Physicochemical Characteristics of the Samples}

Results of the physicochemical assessment of samples collected from the two rivers are presented in Tables 5 and 6. The average characteristic $\mathrm{pH}$ of water and sediment samples from both rivers was a true representative of the condition of the rivers. $\mathrm{pH}$ of water (6.55) and sediment samples (6.67) from River Ogun was found to be

Table 3. Recoveries (\%), limit of detection and limit of quantitation of studied compounds in surface water.

\begin{tabular}{cccc}
\hline${ }^{\mathrm{a}}$ Compounds & \% Recovery & ${ }^{\mathrm{b}} \mathrm{LOD}(\mathrm{ng} / \mathrm{L})$ & ${ }^{\mathrm{c}} \mathrm{LOQ}(\mathrm{ng} / \mathrm{L})$ \\
\hline 4-t-OP & $102 \pm 4.9$ & 0.3 & 1.0 \\
4-NP & $86 \pm 5.3$ & 2.0 & 7.0 \\
BPA & $75 \pm 7.3$ & 0.7 & 2.0 \\
\hline
\end{tabular}

a4-t-OP: 4-tert-octylphenol; 4-NP: 4-nonylphenol; BPA: bisphenol-A; ${ }^{\text {b LOD }}$ Limit of detection; ${ }^{\mathrm{C}} \mathrm{LOQ}$ : Limit of quantitation.

Table 4. Recoveries (\%), limit of detection and limit of quantitation of studied compounds in sediment.

\begin{tabular}{cccc}
\hline${ }^{\mathrm{a}}$ Compounds & \% Recovery & ${ }^{\mathrm{b}} \mathrm{LOD}(\mathrm{ng} / \mathrm{g})$ & ${ }^{\mathrm{c}} \mathrm{LOQ}(\mathrm{ng} / \mathrm{g})$ \\
\hline 4-t-OP & $93 \pm 2.3$ & 0.2 & 0.5 \\
4-NP & $78 \pm 0.3$ & 0.3 & 0.3 \\
BPA & $62 \pm 0.6$ & 0.2 & 0.2
\end{tabular}

${ }^{a}$ 4-t-OP: 4-tert-octylphenol; 4-NP: 4-nonylphenol; BPA: bisphenol-A; ${ }^{\mathrm{b}} \mathrm{LOD}$ Limit of detection; ${ }^{c} \mathrm{LOQ}$ : Limit of quantitation.

Table 5. Physicochemical characteristics of the sediment samples from the studied rivers.

\begin{tabular}{cccccc}
\hline & $\mathrm{pH}$ & \% Clay & \% Sand & \% Silt & \% TOC \\
\hline $\begin{array}{c}\text { River } \\
\text { Ogun }\end{array}$ & $6.67 \pm 0.43$ & $16.4 \pm 9.5$ & $73 \pm 12$ & $7.19 \pm 4.0$ & $2.72 \pm 0.6$ \\
$\begin{array}{c}\text { River } \\
\text { Ibeche }\end{array}$ & $8.12 \pm 0.22$ & $12.5 \pm 5.0$ & $85.4 \pm 6.3$ & $2.05 \pm 2.2$ & $2.36 \pm 0.90$ \\
\hline
\end{tabular}

TOC: Total Organic carbon.
Table 6. Temperature and $\mathrm{pH}$ of water samples from the studied rivers.

\begin{tabular}{ccc}
\hline & Temp $\left({ }^{\circ} \mathrm{C}\right)$ & $\mathrm{pH}$ \\
\hline River Ogun & $27.05 \pm 0.6$ & $6.55 \pm 0.1$ \\
River Ibeche & $23.9 \pm 0.8$ & $7.95 \pm 0.2$ \\
\hline
\end{tabular}

close to neutral. While samples from River Ibeche gave slightly higher $\mathrm{pH}$ value in the region of 7.95 (water) and 8.12 (sediment) at temperatures of $23.9^{\circ} \mathrm{C}$ and $27.05^{\circ} \mathrm{C}$, respectively. The $\mathrm{pH}$ of the samples may be attributed to the composition of various discharges from industrial and domestic activities. Alkylphenols and bisphenol-A have been observed to degrade at a condition of high temperature, particularly above the region of about $60^{\circ} \mathrm{C}$ [28]. However, the average temperature of all the water samples found to be below $30^{\circ} \mathrm{C}$ is assumed to be convenient enough for the persistence of the targeted organic compounds. Sediment samples from both rivers were found to be sandy with percentage sand composition ranging between 73.4\% (River Ogun) - 85.5\% (River Ibeche). On the average, the Total Organic carbon contents of sediment samples from both rivers where found to be close, with TOC of River Ibeche sediments slightly higher than that of River Ogun by about $0.4 \%$.

\subsection{Concentrations of Octylphenol (4-t-OP), Nonylphenol (4-NP) and BPA in River Water Samples}

Analyses of water samples showed that alkyphenolic substances are present in the water samples collected from both rivers. 4-NP, a degradation product of the surfactant, nonylphenol polyethoxylates [29], which have been widely detected in aquatic environments usually at levels of several to hundreds of nanograms per liter [30-32] was found to range between $48.8 \mathrm{ng} / \mathrm{L}-72.3$ $\mathrm{ng} / \mathrm{L}$ and $43.9 \mathrm{ng} / \mathrm{L}-79.4 \mathrm{ng} / \mathrm{L}$ in River Ogun and River Ibeche, respectively as shown in Figure 1. The 4-t-OP, which is approximately $25 \%$ more potent endocrine disruptor than 4-NP [15], was also detected in water samples from both rivers at $57.13 \mathrm{ng} / \mathrm{L}-68.3 \mathrm{ng} / \mathrm{L}$ (River Ogun) and $66.2 \mathrm{ng} / \mathrm{L}-68.6 \mathrm{ng} / \mathrm{L}$ (River Ibeche). The results obtained may be attributed to the continuous discharge of effluents and wastewater from both domestic and industrial activities, particularly River Ibeche which receives effluent from near-by textile industry. Despite the high water solubility of BPA $(120-300 \mathrm{mg} / \mathrm{L})$ [33], the compound was not detected in any of the water samples collected. Most environmental monitoring results showed that the concentration of BPA in rivers is lower than $1 \mu \mathrm{g} / \mathrm{L}$. This may be attributed to the tendency of the compound to adsorb to river sediments. Comparison of the results obtained in this study with work done 


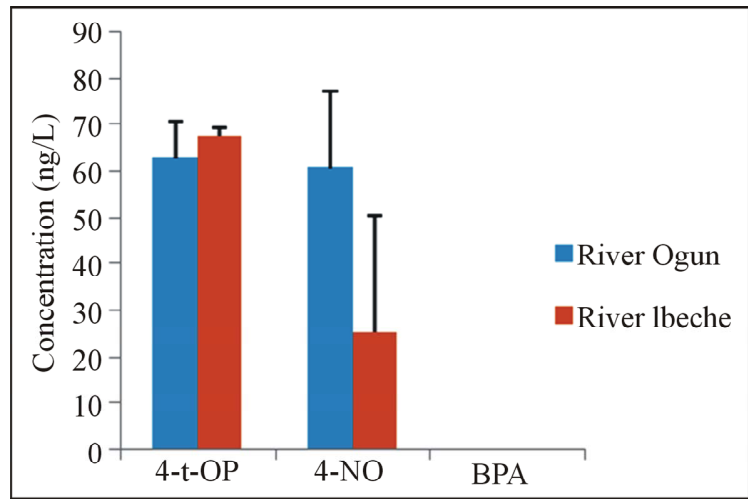

Figure 1. Concentrations of phenolic EDCs in water samples of the studied rivers.

across the world shows that the concentrations of 4-NP and 4-t-OP fall within the range of values obtained in waters assessed from rivers in China and other parts of the world as shown in Table 7.

\subsection{Concentrations of Octylphenol (4-t-OP), Nonylphenol (4-NP) and BPA in Sediment Samples}

Various studies have provided evidence of a long persistence of alkyphenols and BPA in anaerobic sedimentary environment [34]. They have been confirmed to accumulate over long periods of time in sediment and macrophytes due to their hydrophobic nature [1]. Owing to high river flows and sand contents in River Ogun, fine sediment is easily stirred and carried away by the river water. High flow leads to dilution of contaminants and movement of settled sediment [35]. This may therefore explain the low concentrations of 4-t-OP (2.2 ng/g -9.1 $\mathrm{ng} / \mathrm{g})$ and 4-NP (1.1 ng/g - $8.3 \mathrm{ng} / \mathrm{g})$ as depicted in Figure 2. (The error bars represent the standard deviation of the measurements). However, unlike River Ogun, the alkylphenolic concentrations in sediments from River Ibeche were found up to $24.5 \mathrm{ng} / \mathrm{g}$ and $79.4 \mathrm{ng} / \mathrm{g}$ for 4 -tOp and 4-NP, respectively. Despite its higher affinity for sediment, BPA was far less evident than 4-t-OP and 4-NP and could only be found in sediment samples from River Ogun, although at a very low concentration $\leq 0.4$ $\mathrm{ng} / \mathrm{g}$. This value is less than that reported in different studies across the world.

\subsection{Distribution of 4-NP, 4-t-OP and BPA in River Water and Sediments.}

Once a chemical enters an aquatic environment, partitioning of the chemical between water and sediment phase becomes an important process [35]. Due to the moderate hydrophobic nature of phenolic compounds investigated in this study, partitioning of the compounds was expected in the rivers. In addition to the direct partitioning of the dissolved phase fraction of the target compounds from the bulk of the river water to the river bed

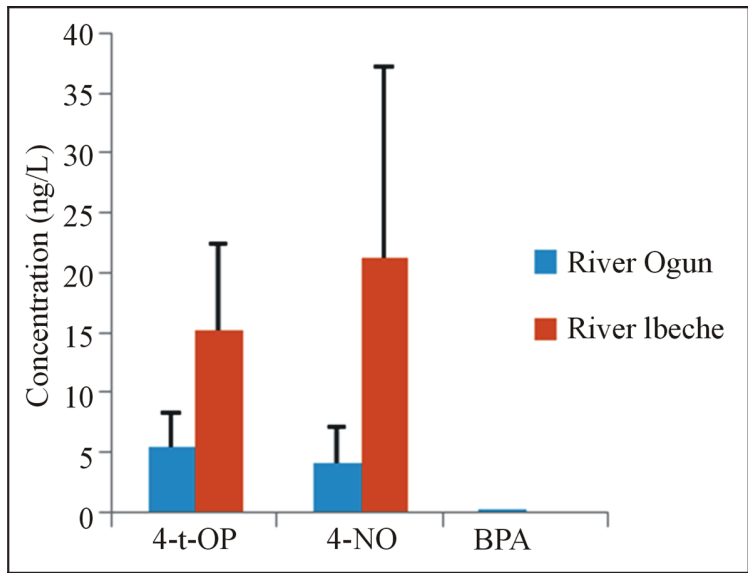

Figure 2. Concentrations of phenolic EDCs in sediment samples of the studied rivers.

Table 7. Comparison of the concentrations of the target compounds in water and sediment in this study and other sites around the world.

\begin{tabular}{|c|c|c|c|c|c|c|c|c|c|}
\hline & \multirow[t]{2}{*}{ Compounds $^{\mathrm{a}}$} & \multicolumn{2}{|c|}{ Africa } & \multicolumn{2}{|c|}{ Asia } & \multirow[b]{2}{*}{ Japan } & \multicolumn{2}{|r|}{ Europe } & \multirow{2}{*}{$\begin{array}{c}\text { America } \\
\text { USA }\end{array}$} \\
\hline & & River Ogun & River Ibeche & China & Korea & & Italy & U.K & \\
\hline \multirow[t]{3}{*}{ Water (ng/L) } & 4-t-OP & $57.13-68.3$ & $66.2-68.6$ & $1.0-2470$ & ND & ND - 819 & - & $<0.3-65$ & - \\
\hline & $4-\mathrm{NP}$ & $48.8-72.3$ & $43.9-79.4$ & $28.1-8890$ & ND - 2448 & ND - 1080 & $<0.5-211$ & $<0.2-8$ & ND - 40,000 \\
\hline & BPA & ${ }^{b} \mathrm{ND}-{ }^{\mathrm{c}}<\mathrm{LOQ}$ & ND & $2.2-1030$ & ND - 39.4 & ND - 600 & $<1.0-145$ & $<0.1-48$ & ND - 12,000 \\
\hline \multirow[t]{3}{*}{ Sediment (ng/g) } & 4-t-OP & $2.2-9.1$ & $9.2-24.5$ & ND - 979 & $3.97-179$ & $3-670$ & - & $<\mathrm{LOQ}-1800$ & ND - 12.5 \\
\hline & 4-NP & $1.1-8.3$ & $6.2-48.3$ & $11.4-28,830$ & $10.4-5054.1$ & $30-13,000$ & $47-192$ & $<$ LOQ - 72,000 & ND - 22.9 \\
\hline & BPA & ND - 0.4 & ND & ND - 296 & $2.7-50.3$ & - & $2.0-118$ & $27-503$ & ND - 5.0 \\
\hline \multicolumn{2}{|c|}{${ }^{\mathrm{d}}$ References } & \multicolumn{2}{|c|}{ This study } & {$[37-39]$} & [41-44] & {$[32,36,40]$} & [45] & {$[46,47]$} & {$[48,49]$} \\
\hline
\end{tabular}

${ }^{\mathrm{a}}$ 4-t-OP: 4-ter-octylphenol; 4-NP: 4-nonylphenol; BPA: bisphenol-A; ${ }^{\mathrm{b}} \mathrm{ND}$ : not detected; ${ }^{\mathrm{c}}<\mathrm{LOQ}$ : below the limit of quantitation. 
sediment, these compounds also have a propensity to partition to particulate organic matter in the river. 4-NP in particular has strong affinity to suspended particulate matter [36]. Therefore, subsequent settling and accumulation of this particulate fraction to river sediments will largely control the mass flux of these compounds within the sediments [35].

Owing to the sandy nature of the sediments samples from both rivers, adsorption of these compounds was found to be very weak based on the calculated Pseudopartitioning coefficients $\left(\mathrm{K}_{\mathrm{d}}\right)$ for the phenolic compounds. The Pseudo-partition coefficients $\left(\mathrm{K}_{\mathrm{d}}\right)$ for the compounds were calculated as the ratio of concentrations in sediment to water phase. The $\mathrm{K}_{\mathrm{d}}$ values $88.2 \mathrm{~L} / \mathrm{Kg}$ and $68.9 \mathrm{~L} / \mathrm{Kg}$ were obtained for 4-t-OP and 4-NP detected in River Ogun, while $2.26 \mathrm{~L} / \mathrm{Kg}$ and $343.6 \mathrm{~L} / \mathrm{Kg}$ were obtained for River Ibeche. No significant partitioning coefficient was obtained for BPA in both rivers. These suggest poor adsorption of these compounds to sandy sediments in both rivers.

\section{Conclusion}

Endocrine disrupting compounds (EDCs) have been detected in aquatic environments (surface water, sediment, and groundwater) worldwide. In this study gas chromatography-mass spectrometric technique was used to determine the level of 4-NP, 4-t-OP and BPA in water and sediments of two major rivers in Lagos, Nigeria. Though in low concentrations, 4-NP and 4-t-OP were detected in water samples from both rivers. No trace of BPA was however detected in the water samples. Despite evidences of high affinity for sediment, BPA could only be found in sediment samples from River Ogun although at a very low concentration. 4-NP and 4-t-OP was also detected in the sediment samples from the two rivers. Poor adsorption of these compounds to the sediments of both rivers was also observed based on the calculated Pseudopartitioning coefficients $\left(\mathrm{K}_{\mathrm{d}}\right)$. In general, this study confirms the presence of endocrine disrupting compounds; BPA, 4-NP, 4-t-OP in some aquatic systems in Nigeria.

\section{REFERENCES}

[1] J. O. Lalah, K. W. Schramm, B. Henkelmann, D. Lenoir, A. Behechti, K. Gunter and A. Kettrup, "The Dissipation, Distribution and Fate of a Branched ${ }^{14} \mathrm{C}$-Nonylphenol Isomer in Lake Water/Sediment Systems," Environmental Pollution, Vol. 122, No. 2, 2003, pp. 195-203. doi:10.1016/S0269-7491(02)00295-6

[2] M. Ahel, and W. Giger, "Aqueous Solubility of Alkylphenols and Alkylphenol Polyethoxylates," Chemosphere, Vol. 26, No. 8, 1993, pp. 1461-1470. doi:10.1016/0045-6535(93)90213-O

[3] T. Mayer, D. Bennie, F. Rosa, G. Rekas, and J. Palabrica,
"Occurrence of Alkylphenolic Substances in a Great Lakes Coastal Marsh, Cootes Paradise, ON, Canada," Environmental Pollution, Vol. 147, No. 3, 2007, pp. 683690. doi:10.1016/j.envpol.2006.09.012

[4] J. L. Zhao, G. G. Ying, L. Wang, J. F. Yang, X. B. Yang, L. H. Yang and X. Li, "Determination of Phenolic Endocrine Disrupting Chemicals and Acidic Pharmaceuticals in Surface Water of the Pearl Rivers in South China by Gas Chromatography-Negative Chemical Ionization-Mass Spectrometry," Science of the Total Environment, Vol. 407, No. 2, 2009, pp. 962-974.

doi:10.1016/j.scitotenv.2008.09.048

[5] J. Liu, R. Wang, B. Huang, C. Lin, Y. Wang, and X. Pan, "Distribution and Bioaccumulation of Steroidal and Phenolic Endocrine Disrupting Chemicals in Wild Fish Species from Dianchi Lake, China," Environmental Pollution, Vol. 159, No. 10, 2011, pp. 2815-2822. doi:10.1016/j.envpol.2011.05.013

[6] Environment Agency UK (EA), "Environmental Risk Evaluation Report: 4-Tert-Octylphenol, Environmental Agency, Rio House, Waterside Drive, Aztec West, Almond- sbury, Bristol, BS32 4UD," 2012.

www.environment-agency.gov.uk

[7] APE Research Council (APERC), "Product Information," 2012. http://www.aperc.org/productinfo.htm

[8] K. Quednow and W. Puttmann, "Endocrine Disruptors in Fresh Water Streams of Hesse, Germany: Changes in Concentration Levels in the Time Span from 2003 to 2005," Environmental Pollution, Vol. 152, No. 2, 2008, pp. 476-483. doi:10.1016/j.envpol.2007.05.032

[9] M. Jonkers, H.-P. Kohler, A. Dammshauser and W. Giger, "Mass Flows of Endocrine Disruptors in the Glatt River during Varying Weather," Environmental Pollution, Vol. 157, No. 3, 2009, pp. 714-723. doi:10.1016/i.envpol.2008.11.029

[10] Y. Q. Huang, C. K. C. Wong, J. S. Zheng, H. Bouwman, R. Barra, B. Wahlström, L. Neretin and M. H. Wong, "Bisphenol-A (BPA) in China: A Review of Sources, Environmental Levels, and Potential Human Health Impacts," Environment International, Vol. 30, No. 1, 2011, pp. 3040.

[11] L. J. Heinis, M. L. Knuth, K. Liber, B. R. Sheedy, R. L. Tunell and G. T. Akley, "Persistence and Distribution of 4-NP Following Repeated Application to Littoral Enclosures," Environmental Toxicology Chemistry, Vol. 18, No. 3, 1999, pp. 363-375. doi:10.1002/etc.5620180302

[12] K. Liber, M. L. Knuth and F. S. Stay, "An Integrated Evaluation of the Persistence and Effects of 4-NP in an Experimental Littoral Ecosystem," Environmental Toxicology and Chemistry, Vol. 18, No. 3, 1999, pp. 357-362. doi:10.1002/etc.5620180301

[13] M. Ahel, W. Giger and M. Koch, "Behavior of Alkylphenolpolyethoxylate Surfactants in the Aquatic Environment: Occurrence and Transportation in Sewage Treatment," Water Research, Vol. 28, No. 5, 1994, pp. 11311142. doi:10.1016/0043-1354(94)90200-3

[14] I.-F. Mao, Y.-Y. Lu and M.-L. Chen, “A Simplified Method for Simultaneous Quantitation of Alkylphenols and 
Alkylphenolethoxylates in Meat and Fish Using HighPerformance Liquid Chromatography with Fluorescence Detection," International Journal of Environmental Analytical chemistry, Vol. 86, No. 10, 2006, pp. 713-722. doi:10.1080/03067310500391971

[15] M. R. Servos, "Review of the Aquatic Toxicity and Bioaccumulation of Alkylphenols and Alkylphenolethoxylates," Water Quality Research Canada, Vol. 34, 1999, pp. 123-182.

[16] F. Pingqing and K. Kimitaka, "Ubiquity of Bisphenol-A in the Atmosphere," Environmental Pollution, Vol. 158, No. 10, 2010, pp. 3138-3143. doi:10.1016/j.envpol.2010.06.040

[17] A. V. Krishnan, P. S. Starhis, F. Permuth, L. Tokes and D. Feldman, "Bisphenol-A: An Estrogenic Substance Is Released from Polycarbonate Flasks during Autoclaving," Endocrinology, Vol. 132, No. 6, 1993, pp. 2279-2286. doi:10.1210/en.132.6.2279

[18] I. Limam, A. Guenne, M. R. Driss and L. Mazeas, "Simultaneous Determination of Phenol, Methylphenols, Chlorophenols and Bisphenol-A by Headspace Solid-Phase Microextraction-Gas Chromatography-Mass Spectrometry in Water Samples and Industrial Effluents," International Journal of Environmental Analytical Chemistry, Vol. 90, No. 3-6, 2010, pp. 230-244. doi:10.1080/03067310903267307

[19] J. A. Brotons, M. F. Olea-Serrano, M. Villalobos, V. Pedraza and N. Olea, "Xenoestrogens Released from Lacquer Coating in Food Cans," Journal of Environmental Health Perspectives, Vol. 103, 1995, pp. 608-612. doi:10.1289/ehp.95103608

[20] C. A. Staples, P. B. Dorn, G. M. Klecka, S. T. O’Block and L. R. Harris, "A Review of the Environmental Fate, Effects and Exposures of Bisphenol-A," Chemosphere, Vol. 36, No. 10, 1998, pp. 2149-2174. doi:10.1016/S0045-6535(97)10133-3

[21] H. Fromme, T. Kuchler, K. Otto Pilz, J. Muller and A. Wenzel, "Occurrence of Phthalates and Bisphenol-A and $\mathrm{F}$ in the Environment," Water Research, Vol. 36, No. 6, 2002, pp. 1429-1438. doi:10.1016/S0043-1354(01)00367-0

[22] N. K. Wilson, J. C. Chuang, and C. Lyu, "Levels of Persistent Organic Pollutants in Several Child Day Care Centers," Exposure, Analytical and Environmental Epidemiology, Vol. 11, No. 6, 2001, pp. 449-458. doi: $10.1038 /$ sj.jea. 7500190

[23] R. A. Rudel, D. E. Camann, J. D. Spengler, L. R. Korn and J. G. Brody, "Phthalates, Alkylphenols, Pesticides, Polybrominateddiphenyl Ethers and Other Endocrine Disrupting Compounds in Indoor Air and Dust," Environmental Science and Technology, Vol. 37, No. 20, 2003, pp. 4543-4553. doi:10.1021/es0264596

[24] L. N. Vandenberg, R. Hauser, M. Marcus, N. Olea and W. V. Welshons, "Human Exposure to Bisphenol-A (BPA)," Reproductive Toxicology, Vol. 24, No. 2, 2007, pp. 139177. doi:10.1016/j.reprotox.2007.07.010

[25] A. M. Calafat, J. A. Wong and L. L. Needham, "Exposure of the US Population to Bisphenol-A and 4-Tertiary-Oc- tylphenol: 2003-2004," Journal of Environmental Health Perspectives, Vol. 116, No. 1, 2008, pp. 39-44. doi: $10.1289 /$ ehp. 10753

[26] A. Walkley, "An Examination of Methods for Determining Organic Carbon and Nitrogen in Soils," Journal of Agricultural Science, Vol. 25, No. 4, 1935, pp. 598-609. doi: $10.1017 / \mathrm{S} 0021859600019687$

[27] A. Goodson, W. Summerfield and I. Cooper, "Survey of Bisphenol-A and Bisphenol-F in Canned Foods," Food Additives and Contaminants, Vol. 19, No. 8, 2002, pp. 796-802. doi:10.1080/02652030210146837

[28] V. Andreu, E. Ferrer, J. L. Rubio, G. Font and Y. Pico, "Quantitative Determination of Octylphenol, Nonylphenol, Alkylphenol Ethoxylates and Alcohol Ethoxylates by Pressurized Liquid Extraction and Liquid Chromatography-Mass Spectrometry in Soils Treated with Sewage Sludges," Science of the Total Environment, Vol. 378, No. 1-2, 2007, pp. 124-129. doi:10.1016/j.scitotenv.2007.01.024

[29] G. G. Ying, B. Williams and R. Kookana, "Environmental Fate of Alkylphenols and Alkylphenolethoxylates: A Review," Environment International, Vol. 28, No. 3, 2002, pp. 215-226. doi:10.1016/S0160-4120(02)00017-X

[30] H. M. Kuck and K. Ballschmiter, "Determination of Endocrine-Disrupting Phenolic Compounds and Estrogens in Surface and Drinking Water by HRGC-(NCI)-MS in the Pictogram Per Litre Range," Environmental Science and Technology, Vol. 35, No. 15, 2001, pp. 3201-3206. doi: $10.1021 / \mathrm{es} 010034 \mathrm{~m}$

[31] G. R. Boyd, J. M. Palmeri, S. Zhang and D. A. Grimm, "Pharmaceuticals and Personal Care Products (PPCPs) and Endocrine Disrupting Chemicals (EDCs) in Storm Water Canals and Bayou St. John in New Orleans, Louisiana, USA," Science of the Total Environment, Vol. 333, No. 1-3, 2004, pp. 137-148.

doi:10.1016/j.scitotenv.2004.03.018

[32] T. Furuichi, K. Kannan, J. P. Giesy and S. Masunaga, "Contribution of Known Endocrine Disrupting Substances to the Estrogenic Activity in Tama River Water samples from Japan Using Instrumental Analysis and in Vitro Reporter Gene Assay," Water Research, Vol. 38, No. 20, 2004, pp. 4491-4501. doi:10.1016/j.watres.2004.08.007

[33] B. Stachel, U. Ehrhorn, O. P. Heemken, P. Lepnon, H. Reincke, G. Sawal and N. Theobald, "Xenoestrogens in the River Elbe and Its Tributaries," Environmental Pollution, Vol. 124, No. 3, 2003, pp. 497-507. doi:10.1016/S0269-7491(02)00483-9

[34] ENDS, "Industry Glimpses New Challenges as Endocrine Science Advances," ENDS Report 290, 1999, pp. 26-30.

[35] L. Wang, G.-G. Ying, J.-L. Zhao, S. Liu, B. Yang, L.-J. Zhou, R. Tao and H.-C. Su, "Assessing Estrogenic Activity in Surface Water and Sediment of the Liao River System in North East China, Using Combined Chemical and Biological Tools," Environmental Pollution, Vol. 159, No. 1, 2011, pp. 148-156. doi:10.1016/j.envpol.2010.09.017

[36] T. Isobe, H. Nishiyama, A. Nakashima and H. Takada, "Distribution and Behavior of Nonylphenol, Octylphenol, 
and Nonylphenol Monoethoxylate in Tokyo Metropolitan Area: Their Association with Aquatic Particles and Sedimentary Distributions," Environmental Science and Technology, Vol. 35, No. 6, 2001, pp. 1041-1049. doi:10.1021/es001250i

[37] B. Chen, J. C. Duan, B. X. Mai, X. J. Luo, Q. S. Yang and G. Y. Sheng, "Distribution of alkyphenols in the Pearl River Delta and Adjacent Northern South China Sea, China," Chemosphere, Vol. 63, No. 4, 2006, pp. 652-661. doi:10.1016/i.chemosphere.2005.08.004

[38] X. Z. Peng, Z. D. Wang, C. Yang, F. R. Chen and B. X. Mai, "Simultaneous Determination of Endocrine-Disrupting Phenols and Steroid Estrogens in Sediment by Gas Chromatography-Mass Spectrometry," Journal of Chromatography A, Vol. 1116, No. 1-2, 2006, pp. 51-56. doi:10.1016/j.chroma.2006.03.017

[39] J. L. Zhao, G. G. Ying, F. Chen, Y. S. Liu, L. Wang, B. Yang, S. Liu and R. Tao, "Estrogenic Activity Profiles and Risks in Surface Waters and Sediments of the Pearl River System in South China Assessed by Chemical Analysis and in vitro Bioassay," Journal of Environmental Monitoring, Vol. 13, No. 4, 2011, pp. 813-821. doi:10.1039/c0em00473a

[40] P. Hohenblum, O. Gans, W. Moche, S. Scharf and G. Lorbeer, "Monitoring of Selected Estrogenic Hormones and Industrial Chemicals in Groundwaters and Surface Waters in Austria," Science of the Total Environment, Vol. 333, No. 1-3, 2004, pp. 185-193. doi:10.1016/j.scitotenv.2004.05.009

[41] J. S. Khim, K. Kannan, D. L. Villeneuve, C. H. Koh and J. P. Gisey, "Characterization and Distribution of Trace Organic Contaminants in Sediment from Masan Bay, Korea by Instrumental Analysis," Environmental Science and Technology, Vol. 33, No. 23, 1999, pp. 4199-4205. doi:10.1021/es9904484

[42] E. J. Ko, K. W. Kim, S. Y. Kang, S. D. Kim, S. B. Bang, S. Y. Hamm and D. W. Kim, "Monitoring of Environmental Phenolic Endocrine Disrupting Compounds in Treatment Effluents and River Waters, Korea," Talanta, Vol. 73, No. 4, 2007, pp. 674-683. doi:10.1016/j.talanta.2007.04.033
[43] S. D. Kim, J. Cho, I. S. Kim, B. J. Vanderford and S. A Snyder, "Occurrence and Removal of Pharmaceuticals and Endocrine Disruptors in South Korean Surface, Drinking, and Waste Water," Water Research, Vol. 41, No. 5, 2007, pp. 1013-1021. doi:10.1016/j.watres.2006.06.034

[44] Z. Li, D. Li, J. R. Oh and J. G. Je, "Seasonal and Spatial Distribution of Nonylphenol in Shihwa Lake, Korea," Chemosphere, Vol. 56, No. 6, 2004, pp. 611-618. doi:10.1016/j.chemosphere.2004.04.022

[45] G. Pojana, A. Gomiero, N. Jonkers and A. Marcomini, "Natural and Synthetic Endocrine Disrupting Compounds (EDCs) in Water Sediments and Biota of a Coastal Lagoon," Environment International, Vol. 33, No. 7, 2007, pp. 929-936. doi:10.1016/j.envint.2007.05.003

[46] M. Petrovic, S. Lacorte, P. Viana and D. Barcelo, "Pressurized Liquid Extraction Followed by Liquid Chromatography-Mass Spectrometry for the Determination of Alkylphenolic Compounds in River Sediment," Chromatography A, Vol. 959, No. 1-2, 2002, pp. 15-23. doi:10.1016/S0021-9673(02)00407-7

[47] Z. L. Zhang, A. Hibberd and J. L. Zhou, "Optimization of Derivatisation for the Analysis of Estrogenic Compounds in Water by Solid-Phase Extraction Gas ChromatographyMass Spectrometry," Analytica Chemica Acta, Vol. 577, No. 1, 2006, pp. 52-61. doi:10.1016/j.aca.2006.06.029

[48] D. W. Kolpin, E. T. Furlong, M. T. Meyer, E. M. Thurman, S. D. Zaugg, L. B. Barber and N. T. Buxton, "Pharmaceuticals, Hormones and Other Organic Waste Water Contaminants in U.S. Streams, 1999-2000: A National Reconnaissance," Environmental Science and Technology, Vol. 36, No. 6, 2002, pp. 1202-1211. doi:10.1021/es011055j

[49] J. D. Stuart, C. P. Capulong, K. D. Launer and X. Pan, "Analyses of Phenolic Endocrine Disrupting Chemicals in Marine Samples by Both Gas and Liquid Chromatography-Mass Spectrometry," Journal of Chromatography A, Vol. 1079, No. 1-2, 2005, pp. 136-145. doi:10.1016/j.chroma.2005.03.075 